\title{
THE CONCEPT OF SEKALA NISKALA IN CREDIT AGREEMENTS AT LABDA PACINGKREMAN DESA BALI TRADITIONAL VILLAGE
}

\author{
Jayanthi Ni Made Devi, Doctoral Candidate \\ Suhariningsih, Safa'at Rachmad, Professors \\ Hamidah Siti, Lecturer \\ Faculty of Law, University of Brawijaya, Malang, Indonesia \\ *E-mail: jayanthidevi91@gmail.com
}

\begin{abstract}
Indigenous Balinese people strive to achieve the ideals of life, namely physical and spiritual well-being (Mokshartam Jagadhita) by means of virtue (dharma). One of the common efforts is to enter into a credit agreement. Credit agreements based on dharma can be made at LPD Bali, a traditional community financial institution, making a credit agreement by harmonizing Balinese customary law and positive law. The harmonization of the two results in a credit agreement that has legal implications, namely applying tri-danda sanctions in resolving disputes that occur later. This study aims to know and understand the concept of a credit agreement based on the dharma. This study uses an anthropological approach that focuses on the philosophy and concepts of sekala niskala law in credit agreements at LPD Bali. Data were obtained through interviews, direct observation, and document studies. Interviews were conducted with prajuru (customary village leaders), LPD administrators, and traditional village communities. Research shows that LPD has and implements the practice of credit agreements with the glocation mechanism, on the one hand following the provisions of the Civil Code and on the other hand incorporating sekala niskala legal concepts according to Hindu teachings adopted by the Balinese indigenous people.
\end{abstract}

\section{KEY WORDS}

Agreement, Sekala Niskala Concept, Balinese Customary Law, Tri Danda.

Today, with the increasingly "capitalist" society, even though they live in the midst of a communal society such as the traditional village community in Bali, the relationship between one community and another (including social institutions) is created in a system that is dominantly formed to meet the needs of the community economy. Thus, the existence of relationships, as well as behavior within and between all parties in the social system, illustrates the existence of a series of processes of human relations that are supported by networks, norms, and social trust that enable efficiency and effectiveness of coordination and cooperation to obtain mutual benefits. Material (whether for personal interest or for the common good).

In their position as traditional villagers who are Hindus, Indigenous Balinese people have a life goal of "moksartham Jagadhita ya ca iti dharma" which means "achieving physical and spiritual well-being must be done by means of virtue". The primary meaning of welfare in the world (jagadhita) tends to lead to economic interests. So that the process of fulfilling the economy becomes a community priority. In fulfilling various interests in achieving prosperity, the community performs various ways, one of which is by making credit agreements.

The Civil Code regulates agreements in Book III (Article 1233-1864) concerning Engagement. Article 1313 of the Civil Code states: "Agreement is an act by which one or more people bind themselves to one or more other people". Subekti said, "agreement is an event where one person promises to another person or where two people promise each other to carry out something". This opinion is in line with the meaning of agreement in Black's Law Dictionary: "an agreement between two or more persons which creates an obligation, to do or not to do a particular thing". To regulate everything related to the agreement requires a law called contract law. A contract is an agreement between two or more people that creates an obligation to do or not to do a certain action. 
According to Article 1, number 11 of the Banking Law, credit is defined as the provision of money or equivalent claims, based on an agreement or loan agreement between a bank and another party that requires the borrower to repay his debt after a certain period with interest. Based on this understanding, a credit agreement can be interpreted as a loan agreement between a bank as a creditor and another party as a debtor, which requires the debtor to repay his debt after a certain period with interest.

Balinese customary law, which is sourced from Hindu religious teachings, interprets the agreement (semaya/pasobayan) following the ideals of their life, namely as a bond of inner and outer relationship to achieve the welfare of physical life (sekala) and the happiness of spiritual life (niskala) of all people not only those who agreed. Thus, it should be realized that the agreement's impact will cause causality (cause and effect) for people who are not even involved in the contract.

Understanding the agreement in Balinese customary law is different from the agreement in general, making the purpose of the credit agreement also different. The purpose of credit agreements, in general, is to regulate the exchange of rights and obligations that are expected to take place properly, fairly, and proportionally according to the agreement of creditors and debtors so that each will benefit (Mertokusumo, 1999). The creditor gets a profit in the form of interest, which becomes a profit for the financial institution concerned, and the debtor gets loan money to meet the needs of life. Meanwhile, the agreement in customary law prioritizes social values, even though there is an economic motive in it, but it is not pure.

Labda Pacingkreman Desa (LPD) is an institution established by the provincial government of Bali to accommodate credit agreement transactions for this purpose. This enforcement is reinforced by Article 39 paragraph (3) of Law Number 1 of 2013 concerning Microfinance Institutions (MFI Law), which confirms that LPDs is recognized as a community financial institution owned by adat which is regulated by customary law so that it is not subject to the MFI Law as long as it still exists. Its existence is recognized and is excluded from the MFI Law. The exceptions provided by the MFI Law are significant for LPDs to affirm their status and position as an extraordinary community financial institution with a very different character from other microfinance institutions. The purpose of developing LPDs is different from other financial institutions, namely helping to preserve Balinese customs and culture, making credit activities carried out by LPDs, as one of the LPD's core businesses, also different. These differences are: (1) Credit disbursement in LPD is not only for profit, but to provide labdha (benefits) that are felt not only by the debtor in an individual context, but throughout the communal village manners; (2) The LPD can only channel credit to the customary village manners where the LPD is located.

The pattern of local wisdom is visible with the inclusion of sekala niskala legal concepts and the Civil Code rules, which cannot be ruled out, especially concerning the terms of the agreement's validity. The concept of sekala niskala law exists as a reminder to the parties who will agree that the purpose of this agreement is a common goal, namely the welfare of the Balinese indigenous people. The Indonesian Civil Code, which is a Dutch heritage, puts forward the spirit of individualism. Likewise, banking regulations that adopt the western economic system tend to be capitalist. These two rules are harmonized with the concept of sekala niskala law to comply with the agreement in Balinese customary law, which has the core of the spirit of unity, harmony, and balance (Budiono, 2015). The characteristics of this harmonious and balanced union can only be extracted from the legal values of the Balinese indigenous people who are famous for the "Tri Hita Karana" philosophy, namely Parhyangan, Pawongan, and Palemahan.

Parhyangan is a harmonious relationship between man and God. This means that the parties must build an agreement on a sacred moral approach (ilikita paiketan pasobayan); Palemahan, namely the harmonious relationship between humans and the environment, means that without realizing the impact of the agreement will lead to causality (cause and effect) for people who are not even involved in the agreement. Although the agreement is made individually, the agreement must not conflict with the normative provisions in society, for example, for the validity of the agreement, it must be based on lawful reasons. Finally, 
Pawongan is a harmonious relationship between humans. This means that a new agreement can be said to be valid if it can balance individual interests with the community's interests because the agreement has a close relationship with the community. In this case, the interest of the individual in the interest of the borrowing community. The interest of the community is the interest of the LPD that belongs to the customary village. The balance is the basis of the agreement. Even long before people are aware of its existence, the principle of balance has been commonly applied.

Even though they have tried to achieve a balance, the parties to the agreement still have to prepare themselves for the non-fulfillment of obligations by one of the parties, leading to a dispute. Anthropologically, everyone in a community has a dispute resolution system and model. For some Indonesians who live in rural areas, especially for those who are indigenous peoples, if there is a dispute between indigenous peoples, the settlement is rarely submitted to the state court. Indigenous peoples feel more like they get justice when they solve problems through customary institutions because the settlement seeks deliberation (peace in consensus).

Referring to this, if there is a dispute in an agreement, the application of the sanctions given must follow the provisions of sanctions in customary law. The purpose of the imposition of sanctions is right on target. In contrast to national law, the purpose of sanctions according to Balinese customary law is to control the disturbed balance due to customary violations. The concept of sekala niskala law is also in line with Soepomo's opinion, which states that about the imposition of sanctions, what is important is that there is a priority in creating a balance between the external world and the unseen world between the whole human group and individuals, between alliances, and friends of the community (Soepomo, 1979).

The embodiment of the local wisdom system, which reflects the local culture in various regions, has indeed been lost from people's memories. That knowledge is no longer complete or acculturated with new knowledge. However, its characteristics are still visible and still function well as a way of life for the supportive community (Safa'at, 2013). In this aspect, it is necessary to research to help gather and rewrite knowledge about Indonesia's original customary treaty law.

\section{METHODS OF RESEARCH}

This research is empirical legal research based on studying the mechanism of applicability and application of the sekala niskala concept in LPD credit agreements. This study emphasizes anthropological studies to obtain a complete and in-depth picture of the legal behavior of LPD administrators, traditional village prajuru (official apparatus), and Balinese traditional village communities as owners and customers of LPDs. The research locations are the Kedonganan Traditional Village LPD, Kapal Traditional Village LPD, and Dukuh Penaban Traditional Village LPD, representing the characteristics of LPDs in South Bali, Central Bali, and East Bali.

The research approach used is ethical and emic. The emic approach is used to answer the first problem to find the meaning of sekala niskala philosophy for the Balinese indigenous peoples, which is then applied in credit agreements in LPD. The emic approach is carried out by in-depth interviews with traditional Balinese community leaders, Balinese Hindu religious figures, and figures involved in the Bali LPD.

An ethical approach will be used to discuss issues regarding the application of sekala niskala in credit agreements in LPDs. The ethical approach is carried out by observing and studying documents.

\section{RESULTS AND DISCUSSION}

Traditional villages in Bali have grown and developed throughout history over the centuries, have genuine autonomy and the right to regulate their households to make a valuable contribution to the survival of community life and development in various fields. However, the autonomy possessed by traditional villages is limited, namely within the 
boundaries of the Unitary State of the Republic of Indonesia (desa destra) (Supartha, 2007). Therefore, as the property of the customary village, in determining the agreement's contents in the credit agreement in the LPD which has a special mission, it should refer to a particular principle. In addition to the general principles of the Civil Code, binding principles in Balinese customary contract law must also be applied.

These principles include:

1. The principle of divinity (Dharma). The principle of divinity is regulated in the Manava Dharmasastra: "Urddhwabahurwiraumyesa naca kaccicchrnoti me, Dharmadarthacca kamacca sa kimartham na sewyate" which means "If you want to seek wealth and lust satisfaction (kama), it should be based on dharma". Therefore, in agreeing, the benefits obtained by both parties from the agreement, if carried out based on dharma, then that is what can be called labha (sacred profit).

2. The principle of loyalty (Satya) consists of:

- Satya Wacana (faithful to words). When an agreement is to be implemented, the LPD as the creditor must convey the truth about the information that the manners must know as a prospective debtor. Vice versa. The main LPD must be open regarding credit interest, term, fines, and collateral in the credit agreement. On the other hand, the debtor's manners must be open primarily regarding the economic condition and the condition of the collateral, especially if the collateral is a movable object, Satya Hredaya (faithful to his conscience), therefore it is obligatory for the parties to avoid all forms of coercion, fraud from any party;

- Satya Mitra (faithful to friendly relations). There is often a clause "credit interest can change at any time without notice" in standard credit agreements". The credit agreement made at the Traditional Village LPD should not include this clause because it denies the Satya principle and can damage friendly relations (business partners).

3. The Principle of Justice (Karmaphala). Karmaphala consists of three parts, containing the time of receiving the results of these actions, namely:

- Sancita Karmaphala, meaning that actions in the past/past lives in this life we receive the results of these actions;

- Prarabda Karmaphala, meaning actions in the present/present life in this present life, we also receive the results of these actions;

- Kryamana Karmaphala, meaning actions in the present/present life in future lives, we receive the results of these actions.

Karmaphala in the form of scale that can befall the party who reneges on obligations is prarabda karmaphala. If krama reneges on the agreement, the collateral held by the debtor's krama can be confiscated by the LPD. However, if the LPD manager reneges on the agreement, the person concerned can be dismissed as manager. The niskala relationship in the context of karmaphala is related to kryamana karmaphala, were breaking a promise will get social sanctions from society that can be felt in the future even by posterity their pride has fallen in the eyes of society.

A credit agreement that is valid and has legal force must first meet the requirements for a valid agreement. The conditions for the validity of the agreement are regulated in Article 1320 of the Civil Code. In addition to valid agreements according to Article 1320 of the Civil Code, they are recognized by law. On the contrary, according to Article 1320 of the Civil Code, invalid agreements are not recognized by law even though they are recognized by the parties concerned. The niskala credit agreement does not explicitly regulate the conditions for the validity of the agreement. Thus, purely the conditions for the validity of the agreement based on the Civil Code are used as a reference by making adjustments based on the kala patra village (mawacara village), as long as it does not conflict with government regulations.

1. There is an agreement:

Agreement as a valid condition of the agreement must be freely given. Civil law will reject the agreement's validity if the agreement that appears in it contains impunity, namely the emergence of the agreement was caused by mistake, coercion, and fraud, as stated in Article 1321 of the Civil Code. This provision is in line with the context of the agreement in 
the agreement based on Balinese customary law as regulated in the Arthasastra Manuscript Chapter I Section 57 concerning the Determination of Legitimate and Illegal Transactions: night time, in the woods, by deception, or done in secret".

Apart from being a form of openness under the principle of light, the presence of the parties is also a form of respect for each party. The parties who take the time to attend show good faith in respecting the agreement because they feel they have balanced rights and obligations. Neither party needs the other more. Attendance is a must to minimize an agreement that arises due to mistake/negligence, fraud/deceit, or threats, both physical and psychological.

2. Ability to make agreements:

Regarding this skill, there are provisions called full proficiency and partial proficiency. A person is said to be fully competent if he has the status of civil servants, is married, has replaced his parents to carry out the rights and obligations of the Banjar, is financially independent. Meanwhile, partial competence applies to: (1) a person who has the status of village manners, is not yet a civil servant, is not married, but is financially independent and carries out the rights and obligations of the traditional village; (2) or someone who has the status of village manners, is not yet a civil servant, is married, but is not financially independent and carries out the rights and obligations of the traditional village.

In determining the age of proficiency, based on Hinduism in the teachings of catur asrama, the age of 21 is also agreed upon as the ideal age. Because at that age, a person has completed his education period (Brahmacari asrama), so he is ready to work for his own household life (Grhsta asrama). Ideally, during this time of brahmacari and grhsta, someone is perfectly capable of being a party to the agreement. The cycle of changing the age of marriage, referred to as the wanaprasta stage, focuses on the concentration of the mind to achieve spiritual well-being. Lastly is the sanyasin stage, where one focuses on attaining moksha (union with God).

3. There is a certain thing:

Article 1337 of the Civil Code to determine whether the clauses or terms and conditions in a standard agreement can apply and can bind the parties. The benchmarks are; (1) laws (wet), (2) morals (goede zeden), (3) public order (openbare order). This provision is also contained in Manava Dharmasastra 164 which states that: "Satya na bhasa bhawati yadyapi syatprati sthita, bahicced bhasyate dharman niyato dwayawaharikat". This provision means that if the agreement that has been made is contrary to the laws and customs that have been recognized by the community, then the act of the agreement still has no legal force.

4. There is a lawful cause:

The Traditional Village LPD has the right to collect credit refunds from the moment it is proven that the funds have not been used according to their designation when applying for credit. In addition to maintaining the smoothness of credit payments, from the Hindu religion perspective, there are provisions regarding sins inflicted on the lender if the borrower uses the borrowed money for negative things.

Several traditional villages in Bali apply unique provisions regarding krama tamiu (outside the traditional village) in borrowing money, such as the LPD Traditional Village Padangluwih, "a krama tamiu who wants to make a credit transaction, is obliged to pay niskala administration, in the form of payment of funds of $0.5 \%$ of the ceiling. credit". "Generally, the provisions regarding this punia fund can be found in traditional villages with heterogeneous population characteristics. This means that more migrants live in the traditional village than local people. This is intended as an expression of the pole nyelang jebos (I beg your pardon) in a notional manner to the ancestors and the Bhatara (God) as the "owner" of the traditional village concerned".

5. There are witnesses:

The fundamental difference between the legal terms of the agreement based on the Civil Code and Balinese customary law is the urgency of the presence of witnesses. Witnesses in Balinese customary law agreements also determine the validity of the agreement. In credit agreements at conventional financial institutions, the presence of witnesses is not part of the conditions for the validity of the agreement, because credit 
agreements are generally only made under the hand, so that the presence of witnesses is not mandatory, as in a notarial agreement. Even if there are witnesses, generally, the witnesses used are financial institution office employees or notary office employees who have met the requirements as witnesses. In addition, the deed of binding guarantee (fiduciary and mortgage) made by the Land Deed Making Officer (PPAT) is also considered to have more proving power than testimony in the event of a dispute in court.

The existence of witnesses is an absolute must. To create a strong moral bond to fulfill promises and minimize disputes in the future. Witness in Balinese customary law is a formality but has a magical religious power with "pushing power" and even "coercion" for the parties to carry out their respective obligations. In Arthasastra, as a source of Hindu law, a person can even be subject to sanctions if he is willing to witness agreements/transactions that are not permitted (Kautilya, 2003).

6. Place and Time of Agreement:

Almost all LPDs in Bali apply special time provisions regarding the prohibition of conducting financial transactions, including credit. These times, namely; Rahina Buda Cemeng Klawu, Rahina Saraswati, and Rahina Galungan Kuningan. The three holidays, according to customs, especially Buda Cemeng Klawu, Ida Betari Rambut Sedana / Dewi Laksmi are doing yoga (tapa brata). It is also believed that today it is not allowed to use the money for things that are not returned in the form of goods, For example, paying debts or saving, because it is believed that the money/wealth will not be able to return forever and disappear by our greedy nature as humans.

The customary credit agreement with the concept of sekala niskala law includes the divine instructions "Om Atah Paramawisesa" as a reminder that the agreement was made on a sacred moral basis. Then proceed with the medewa saksi or taking the oath at one of the Kahyangan Tiga Temples. The Kedonganan Traditional Village LPD and Muntigunung Traditional Village LPD apply this rule.

In addition to the inclusion of the clause in the credit agreement, to strengthen the existence of sekala niskala legal concept that will be applied concerning preventive measures to ensure smooth credit payments, it is carried out by implementing medewa saksi ceremony before signing credit The medewa saksi ceremony is carried out using a pekeling offering. Pekeling comes from the word eling which means remember. So that the banten pekeling has the meaning of a reminder that the krama who performs the medewa saksi ceremony must pay. The medewa saksi ceremony held at one of the Kahyangan Tiga Temples shows that the debtor's manners must remember that their obligations are to the LPD and the traditional village. The Muntigunung Traditional Village LPD also applies a similar oath to the Kedonganan Traditional Village LPD. However, after signing the credit agreement, taking the oath is done before the credit funds are disbursed. The swearing of the oath was even carried out at the Padmasana LPD of the Muntigunung Traditional Village. The utterance of this oath is called the medewa saksi ritual.

Regarding the application of credit interest, interest money is included with Madya Dana, namely, making money from trading. Before entering a financial institution into a traditional village, the Balinese indigenous people did not know the term interest money. They often refer to the parent loan money taken by the borrower as "panak pis". Mutranin or Manakang jinah is another name for "panak pis". Mutranin comes from the word "putra" and manakang comes from the word "panak" or "pianak". Both terms mean child. So that mutranin or manakang both mean "to give birth".

I Dadong pidan men ade nak nyilih pis, orange be Nyanan pise ne mepanak nah. $\mathrm{Ne}$ nentuang to kan liu, engken je situasine, nyen ne nyilih. Dikenkeni ye ngidang nyatusin istilahne duang persen, nyeketin to besik, tegehang biin ngidang kanti nasahin. Nyiliang pis sing terus, pas je anake sing ngidang ngalih be, mare ye (My mother used to borrow money. She would say that your loan had an interest. Depending on the situation, depending on who is borrowing, the amount can vary. It could be two percent which is termed nyatusin, if the clicking is another term for one (percent), it could even be up to ten percent. Lending money is also not the primary profession, only done when fishers cannot go to sea). 
Some do not apply a percentage, but interest is taken at $1 / 3$ of the principal value of the debt. This provision refers to Sarasamuccaya sloka 262, the proceeds of a business must be distributed among three groups: 1/3 property (reinvestment), 1/3 dharma (ceremony), 1/3 kama (wish). This tradition is called the pahtelu tradition, or some call it the pertelu. Pahtelu comes from the word "pahpah" which means cut. So, pahtelu or pertelu means "divided by 3 ".

Even though they have tried to achieve a balance, the parties to the agreement still have to prepare themselves for non-fulfillment of obligations by one of the parties, leading to a dispute. Anthropologically, everyone in a community has a dispute resolution system and model. For some Indonesians who live in rural areas, especially for those who are indigenous peoples, if there is a dispute between indigenous peoples, the settlement is rarely submitted to the state court. Indigenous peoples feel more like they get justice when they solve problems through customary institutions because the settlement seeks deliberation (peace in consensus).

Referring to this, if there is a dispute in an agreement, applying the sanctions given must follow the provisions of sanctions in customary law. Thus, the purpose of the imposition of sanctions is right on target. In contrast to national law, the purpose of sanctions according to Balinese customary law is to control the disturbed balance due to customary violations. The concept of sekala niskala law is also in line with Soepomo's opinion, which states that about the imposition of sanctions, what is important is that there is priority in creating a balance between the external world and the unseen world between the whole human group and individuals, between alliances, and their friends (Soepomo, 1979).

There is a type of sanction known in Balinese customary law, which is one of the embodiments of the concept of sekala niskala law, termed tri danda (three fines/sanctions). Tri danda is generally contained in awig-awig adat villages, either explicitly or implicitly. However, suppose it will be applied as a sanction to traditional village communities who make mistakes. In that case, they must prioritize paras-sparo (togetherness-family), gilik saguluk (consensus deliberation), salunglung sabayantaka (a sense of shared fate), sarpana ya (in the rhythm of agreement). The parts of the Tri Danda are (Widnyana, 1992):

1. Arta Danda, namely a group of customary sanctions in the form of material, namely by paying money or replacing property (material objects);

2. Jiwa Danda, namely the group of sanctions in the form of physical and/or spiritual/mental suffering, such as mengaksama, mapilaku, lumaku, olas, nyuaka (apologizing), kasepekang (ostracized), until the most severe is kanorayang (dismissed as a customary manner );

3. Sangaskara Danda, namely sanctions in carrying out certain ceremonies to restore magical balance and carried out under Hindu religious teachings). The implementation of customary sanctions through religious traditions in Bali is usually with a hug and cleansing ceremony called Pamarisudhan or Maprayascitta. The Pamarisudhan ceremony or Maprayascitta is a form of traditional ceremony in Bali that can neutralize or cleanse the community and the area where an event or violation of customs occurs.

The imposition of sanctions in the form of Arta Danda and Jiwa Danda, which is applying the concept of the Sekala law, is a type of sanction usually used to the Balinese indigenous peoples but also to other indigenous peoples in Indonesia in general. Therefore, the privilege of the Tri Danda sanction in Balinese customary law lies in the imposition of Sangaskara Danda, which is the application of the concept of Niskala law because it has a religious meaning.

\section{CONCLUSION}

Harmonization of the Civil Code and the concept of sekala niskala law will make credit agreements in LPD Traditional Village more ideal because they accommodate Balinese customary law without compromising the existence of positive law. From the phenomenological aspect, the credit agreement formed will be under the meaning, 
characteristics, experience, and feelings of the indigenous people themselves. In addition, it was found that Balinese customary law itself was able to animate civil law both in terms of the principles of the agreement, the terms of the validity of the agreement, the rights and obligations of the parties in the agreement to the dispute resolution process.

The concept of sekala niskala law must be applied in credit agreements in LPD Traditional Village based on Balinese customary law to create a strong moral bond to fulfill promises and minimize disputes that end in court. The existence of the concept of sekala niskala law in Balinese customary law is not only complementary. Sekala provides external pressure, is rational (human law/society), and Niskala provides internal pressure from within and is religiously magical based on belief in God. So that the synergy between the two will create a stronger "push" and even "force" for the parties to carry out their respective obligations.

\section{REFERENCES}

1. Kautilya, C. (2003). Arthasastra. Surabaya: Paramita.

2. Black, H. (1990). Black Law Dictionary Sixth Edition: St. Paul Minn: West Publishing Co.

3. Budiono, H. (2015). Asas Keseimbangan bagi Hukum Perjanjian Indonesia (Hukum Perjanjian Berlandaskan Asas-Asas Wigati Indonesia. Bandung: Citra Aditya Bakti.

4. Soebekti, R \& Tjitrisadibio, R. (1976). KUHPerdata (Burgelijk Wetboek). Jakarta: Pradya Paramita.

5. Safa'at, R. (2013). Rekonstruksi Politik Hukum Pangan (dari Ketahanan Pangan, ke Kedaulatan Pangan). Malang: UB Press, Malang.

6. Soepomo. Bab-bab Tentang Hukum Adat. Jakarta: Pradnya Paramita.

7. Subekti. Pokok-Pokok Hukum Perdata. Jakarta: Intermasa.

8. Mertokusumo, S. (1999). Mengenal Hukum: Suatu Pengantar. Yogyakarta: Liberty.

9. Supartha, I. (2007). Talenta Bali Menuju Otonomi Khusus. Denpasar: Pansus Otsus DPRD Provinsi Bali.

10. Widnyana, I. (1992). Eksistensi Delik Adat Dalam Pembangunan (Orasi Pengukuhan Doktor di Fakultas Hukum Universitas Udayana). Denpasar: Fakultas Hukum Universitas Udayana.

11. Windia, W. (2016). Materi Kuliah Umum Hukum Pidana: Pidana Adat dan Relevansinya dengan Perubahan Hukum Pidana Nasional. Denpasar: Fakultas Hukum Universitas Udayana Universitas Udayana. 